\title{
Evaluation of exposure to ethylene glycol monoethyl ether acetates and their possible haematological effects on shipyard painters
}

Yangho Kim, NaRoo Lee, Tadashi Sakai, Kyoo-Sang Kim, Jeong Sun Yang, Seunghyun Park, Choong Ryeol Lee, Hae-Kwan Cheong, Younghahn Moon

Industrial Health

Research Institute, Korea Industrial Safety Corporation (KISCO) 34-6, Kusan-Dong,

Bupyeong-Ku, Incheon 403-711, South Korea Y Kim

NR Lee

K-S Kim

J S Yang

S Park

Y Moon

Center of

Occupational

Medicine, Tokyo Labor

Accident Hospital, 13-21 Omoriminami-4, Ota-ku, Tokyo 143,

Japan

T Sakai

Department of Occupational

Medicine, Hospital of

Ulsan University,

Ulsan, South Korea

C R Lee

Department of

Preventive Medicine,

College of Medicine,

Dongguk University,

Kyongju, South Korea

H-K Cheong

Correspondence to:

Dr Yangho Kim, Industrial

Health Research Institute,

Korea Industrial Safety

Corporation (KISCO) 34-6,

Kusan-Dong, Bupyeong-Ku,

Incheon 403-711, South

Korea. Fax 008232518

0862 .

Accepted 18 December 1998

\begin{abstract}
Objectives-To evaluate exposure to mixed solvents containing ethylene glycol monoethyl ether acetate (EGEEA) in shipyard painters, to determine if EGEEA is toxic to the bone marrow.

Methods-An industrial hygiene survey was performed to identify exposure to EGEEA of two groups of shipyard painters, a low exposure group $(n=30)$ and a high exposure group $(n=27)$. Urinary ethoxyacetic acid and methyl hippuric acid as well as haemoglobin, packed cell volume, red cell indices, total and differential white blood cell counts (WBCs), and platelet count for the shipyard painters and the control subjects were measured. Results-The mean (range) exposure concentration (ppm) to EGEEA in the high and low exposure groups were 3.03 (not detectable to 18.27), 1.76 (not detectable to 8.12), respectively. The concentrations of methyl hippuric acid and ethoxyacetic acid in the high exposure group were significantly higher than those in the control group. The mean WBCs in the high exposure group were significantly lower than in the control group, and a significant proportion, six $(11 \%)$ of the 57 painters, were leucopenic; none of the controls were affected.

Conclusion-The high rate of possible haematological effects among shipyard painters and a hygienic evaluation of their working environment in the present study suggests that EGEEA might be toxic to bone marrow.
\end{abstract}

(Occup Environ Med 1999;56:378-382)

Keywords: leucopenia; hypocellular marrow; granulocytopenia; ethoxyacetic acid; ethylene glycol monoethyl ethers

Ethylene glycol ethers - such as ethylene glycol monoethyl ether (EGEE), ethylene glycol monomethyl ether (EGME), ethylene glycol monoethyl ether acetate (EGEEA), and ethylene glycol monomethyl ether acetate (EGMEA), are colourless liquids, and are miscible with water and many organic solvents. They are widely used as industrial solvents for resins, lacquers, dyes, paints, and inks. Animal experiments and human case reports show that ethylene glycol ethers have a potentially important impact on the haematopoietic and reproductive systems. ${ }^{12}$
Although many workers are potentially exposed, the published airborne exposure data on ethylene glycol ethers, especially EGEEA, are limited. ${ }^{3}{ }^{4}$ It is also important to note that air sampling only poorly identifies the potential for exposure to ethylene glycol ethers. They are rapidly absorbed through the skin, and some studies suggest that skin absorption may be a more important route of exposure than inhalation. ${ }^{56}$ Hence, the rare biological monitoring of workers exposed to EGEEA by measurement of ethoxyacetic acid (EAA) excreted in urine is particularly important for assessing occupational exposure. ${ }^{47}$ In the animal study by Nagano et al, ${ }^{1}$ EGEEA administered orally to mice for 5 weeks produced leucopenia in peripheral blood as well as marked testicular atrophy, with a doseresponse relation. In another animal experiment, EGEEA applied to rats by skin contact caused a considerable decrease in peripheral white blood cell count (WBC). ${ }^{8}$ However, the health effects of EGEEA on humans have not been reported.

A cross sectional study of shipyard workers with and without potential occupational exposures to mixed solvents containing EGEEA was conducted. The objectives of the study were to evaluate exposure to mixed solvents containing EGEEA in shipyard painters, and to find if EGEEA is toxic to the bone marrow.

\section{Materials and methods}

JOB DESCRIPTION

Painters, mostly men, employed at the shipyard were separated into two types of crews-tank crews and deck house crews. Tank crews (group A) apply paint to block units of assembled ships. The main tank crew workers wear respirators as they apply paint primarily in spray form in tanks or other closed spaces. The assistant tank crew workers are those who mix paint or assist the main crews. The assistant workers seldom wear half face cartridge respirators.

The deck house crews (group B) are involved in various jobs - such as spraying or brush painting, wiping, or surface preparation for painting. Half face cartridge respirators are available to these men, but their use is at the discretion of the individual painters.

SUBJECTS

The shipyard employed about 900 painters, consisting of many groups. From each of these groups in the factory, we randomly selected 
one tank crew, total 32 workers, as a high exposure group, and one deck house crew, total 29 workers, as a low exposure group. The few women randomly selected were not included in the study population, thus leaving for examination 30 and 27 workers in groups $\mathrm{A}$ and $\mathrm{B}$, respectively.

As controls, we examined all 41 workers in one non-production section of the same factory. They worked mainly in the office in a building separated from the production section, and sometimes patrolled the factory to prevent industrial accidents. We thought that they had no potential exposure to EGEEA, and thus they were not monitored with personal air samplers.

ENVIRONMENTAL MONITORING

For personal breathing zone air samples two trained industrial hygienists selected 18 and 12 painters from groups A and B, respectively; their exposures were thought to be representative for each group. Personal sampling pumps connected to two types of charcoal tube were used. One was for sampling and analysis of hydrocarbons at a flow rate of $50-200 \mathrm{ml} / \mathrm{min}$ (NIOSH method 1501), the other for alcohols of which the flow rate was $10-50 \mathrm{ml} /$ $\min (\mathrm{NIOSH}$ method 1403).

All pumps were calibrated before and after use. Sampling was carried out for at least 6 hours excluding breaks. Bulk samples of some paints and thinners, representative of those most used during the sampling period and in the recent past, were taken on site in the workplace and were put into vials. Samples were sent to the Industrial Health Research Institute of the Korean Industrial Safety Corporation, designated as the reference laboratory by the Korean government. This laboratory has been proficient in the analytical testing programme of the American Industrial Hygiene Association since 1992 and has performed internal quality control programmes. Analysis was performed by gas chromatography $(5890$ II, Hewlett Packard, CA, USA) according to NIOSH analytical methods 1501 and 1403.

Gas chromatographs with a mass selection detector (GC-MSD, 5871 II, Hewlett Packard, CA, USA) were used to assess the contents of bulk samples. A detailed industrial hygiene investigation was done on current work practices and control measures including ventilation.

BIOLOGICAL MONITORING

Urine samples were collected to measure EAA, hippuric acid (HA), and methyl hippuric acid (MHA) from the exposed and control groups at the end of the shifts at the end of the workday. Urinary EAA was measured with gas chromatography and flame ionization detection (GC-FID, Shimazu GC-9AM, Shimazu, Kyoto, Japan) and a capillary column (HR20M, $50 \mathrm{~m}$ long, $0.25 \mathrm{~mm}$ internal diameter, $0.25 \mu \mathrm{m}$ film thickness, Shinwa Kako, Kyoto, Japan) by the Sakai method. ${ }^{4}$ Urinary HA and MHA were measured by high performance liquid chromatography (Shimazu LC-3A, Shimazu, Kyoto, Japan). Urinary metabolites were corrected for the concentration of urinary creatinine. The lead concentration of whole blood was analysed with flameless atomic absorption spectrometry (Varian SpectraAA, Varian Techtron Pty, Victoria, Australia). The laboratory in the Industrial Health Research Institute has participated in the comparison programme in Germany for occupational and environmental medicotoxicological analyses, and has fulfilled the requirements for two variables, blood lead and urinary hippuric acid, for 2 years.

QUESTIONNAIRES AND LABORATORY TESTING Each participant was seen at the factory clinic. We administered a questionnaire and collected samples of blood and urine. The questionnaire elicited basic demographic information and information about smoking, alcohol consumption, medications, and recent medical history. Each participant was asked about his work history, environmental exposure, and leisure time exposure in detail.

A sample of blood was obtained for a complete blood count. The count was run within 8 hours with a Coulter counter to reduce variation of WBCs, and the following data were collected: WBCs, haemoglobin $(\mathrm{Hb})$, red blood cell count (RBC), packed cell volume (Hct), platelet count (Plt), mean corpuscular volume (MCV), mean corpuscular haemoglobin $(\mathrm{MCH})$, mean corpuscular haemoglobin concentration (MCHC), differential count, peripheral blood smear (PBS).

Bone marrow aspiration was done in the iliac crest on three consistently leucopenic workers. Liver function testing - such as aspartate aminotransferase, alanine aminotransferase, and $\gamma$-glutamyltransferase-was done to rule out chronic liver disease. The laboratory tests were analysed at a nearby university hospital.

STATISTICAL ANALYSES

Mean values for $\mathrm{Hb}$, Hct, RBC, WBC, Plt, $\mathrm{MCV}, \mathrm{MCH}$, and $\mathrm{MCHC}$ for the two exposure groups and one control group were compared by one way analysis of variance (ANOVA). If the ANOVA showed significance at $p<0.05$, Scheffe's multiple comparison test was used to identify which group was significantly different from which other group. Correlations among variables were evaluated with Pearson's correlation coefficients.

The proportion of men with leucopenia in each group was compared by Fisher's exact test.

Analyses by multiple regression modelling on WBCs were also performed to control for the influence of age, alcohol consumption, smoking, and duration of work.

For leucocyte count, $4500-11000$ cells/ $\mu \mathrm{l}$ is generally regarded as the normal range in adults. We used a value of $<4500$ cells $/ \mu$ l as a cut off point for leucopenia to detect the early changes of leucocyte count, although many laboratories worldwide define leucopenia as $<4000$ cells $/ \mu 1$.

\section{Results}

Toluene, ethyl benzene, xylene, butanol, isopropanol, ethanol, ethyl acetate, butyl acetate, 
Table 1 Summary of airborne exposure (ppm) in shipyard painters (geometric mean (range))

\begin{tabular}{lcl}
\hline Worker group & Group $A(n=18)$ & Group $B(n=12)$ \\
\hline Toluene & $12.02(\mathrm{ND}-154.59)$ & $0.73(0.05-8.55)$ \\
Xylene & $28.23(1.07-249.81)$ & $8.50(1.19-74.04)$ \\
Methl isobutyl ketone & $4.60(0.03-159.18)$ & 1.41 (ND-6.86) \\
EGEEA & $3.03($ ND-18.27) & 1.76 (ND-8.12) \\
\hline
\end{tabular}

$\mathrm{ND}=$ non detectable.

Table 2 Urinary hippuric acid (g/g creatinine), methyl hippuric acid (g/g creatinine), and ethoxyacetic acid concentrations ( $m g / g$ creatinine) of control subjects and painters exposed to EGEEA (geometric mean/geometric SD (range))

\begin{tabular}{llll}
\hline Worker group & Group $A(n=25)$ & Group $B(n=26)$ & Control group $(n=40)$ \\
\hline Hippuric acid & $0.2 / 2.5(\mathrm{ND}-1.1)$ & $0.1 / 2.4(\mathrm{ND}-1.1)$ & $0.2 / 2.0(\mathrm{ND}-0.7)$ \\
Methyl hippuric acid & $0.08 / 6.13^{\star \star}(\mathrm{ND}-1.31)$ & $0.03 / 3.77(\mathrm{ND}-0.17)$ & $0.01 / 2.37(\mathrm{ND}-0.1)$ \\
Ethoxyacetic acid & $9.2 / 5.6^{\star \star}(\mathrm{ND}-227.3)$ & $0.6 / 11.3(\mathrm{ND}-15.1)$ & $0.1 / 2.6(\mathrm{ND}-1.5)$
\end{tabular}

$\star \star \mathrm{p}<0.01 v$ group $\mathrm{B}$ and control group.

$\mathrm{ND}=$ non-detectable.

Urine samples of seven painters were not collected.

Table 3 Demographic and hematological findings of the study population (mean (SD))

\begin{tabular}{llll}
\hline & $\begin{array}{l}\text { Group } A \\
(n=30)\end{array}$ & $\begin{array}{l}\text { Group } B \\
(n=27)\end{array}$ & $\begin{array}{l}\text { Control group } \\
(n=41)\end{array}$ \\
\hline Age $(\mathrm{y})$ & $37.4(8.5)$ & $39.2(4.4)$ & $39.3(7.5)$ \\
Duration of work (y) & $8.0(5.4)$ & $11.0(0.7)$ & $11.0(6.6)$ \\
Smoker $(\%)$ & 73 & 70 & 50 \\
Drinker $(\%)$ & 87 & 82 & 85 \\
Haemoglobin $(\mathrm{g} / \mathrm{dl})$ & $14.37(0.8)$ & $14.7(1.0)$ & $14.6(0.8)$ \\
Red blood cells $\left(10^{4} / \mu \mathrm{l}\right)$ & $474(32)$ & $482(39)$ & $489(29)$ \\
White blood cells $(/ \mu \mathrm{l})$ & $6033(1433)^{\star}$ & $6325(1410)$ & $7031(1400)$ \\
Granulocytes $(/ \mu \mathrm{l})$ & $3210(1351)^{\star}$ & $3543(1361)$ & $3966(1167)$ \\
Packed cell volume $(\%)$ & $42.9(2.3)$ & $43.4(2.6)$ & $43.4(2.0)$ \\
Platelets $\left(10^{3} / \mu \mathrm{l}\right)$ & $255(64)$ & $260(58)$ & $249(49)$ \\
Mean corpuscular volume & $90.7(3.5)^{\star}$ & $90(3.9)$ & $88.6(3.1)$ \\
Mean corpuscular haemoglobin & $30.3(1.0)$ & $30.6(1.4)$ & $30(1.2)$ \\
Mean corpuscular haemoglobin concentration & $33.5(0.7)$ & $34(0.8)$ & $33.5(1.9)$ \\
\hline
\end{tabular}

${ }^{\star} \mathrm{p}<0.05 v$ reference group.

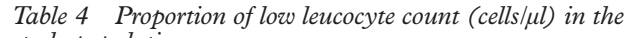
study population

\begin{tabular}{llll}
\hline & $<4500$ & $\geqslant 4500$ & Total \\
\hline Exposed group & 6 & 51 & 57 \\
Control group & 0 & 41 & 41 \\
Total & 6 & 92 & 98 \\
\hline
\end{tabular}

${ }^{\star} \mathrm{p}<0.05$.

values exceeding the TLV-TWA in group A were sprayers. Four (22\%) of 18 workers in group A had values for xylene exceeding 100 $\mathrm{ppm}$, its TLV, one had values for toluene exceeding $50 \mathrm{ppm}$, its TLV, and one had values for methyl isobutyl ketone exceeding $50 \mathrm{ppm}$, its TLV.

Table 2 summarises the urinary concentrations of three acids in control subjects and workers exposed to the paints. Detection limits for EAA, HA, and MHA were 0.1, 50, and 10 $\mathrm{mg} / \mathrm{l}$ urine, respectively. The concentrations of MHA and EAA in the high exposure group A were significantly higher than those in the control subjects $(p<0.05)$, in whom very low concentrations of EEA and MHA supported nonexposure to mixed solvents. The correlation coefficient of EAA with log EGEEA was 0.40. The mean (range) of blood lead concentrations was $7.5(3.3-19) \mu \mathrm{g} / \mathrm{dl}$, indicating nonexposure to lead.

As shown in table 3, there were no significant differences in mean age, the duration of work, and the proportion of smokers and drinkers among the three groups ( $p>0.05)$. The mean WBC and granulocyte counts in the two exposure groups were not significantly different. There was a significant difference, however, between the more exposed group $\mathrm{A}$ and the control group. The mean for MCV in the more exposed group was also higher than that for the control group $(p<0.05)$, although the mean concentrations of $\mathrm{Hb}$ or packed cell volumes did not differ among the subjects. (table 3). A significant proportion, six $(11 \%)$ of 57 , painters were leucopenic $(<4500)$, but none of the controls were affected $(\mathrm{p}<0.05$, table 4$)$. In the leucopenic workers WBCs were 3200, 3800, 4300,4300 , and 4400 cells/ $\mu$ in group A, and 4200 cells/ $\mu$ in group B.

Multiple linear regression showed that subjects in groups A and B had less WBCs than the control group after controlling for smoking and alcohol consumption, and the decrease in WBCs was greater in group A. Smoking was shown to increase WBCs, after controlling for study groups and other confounders. Age and duration of work were not confounders (table 5, model 1). Concentrations of EAA also decreased WBCs when EAA concentrations were substituted for study groups. Similar relations were found for smoking (table 5, model 2).

The bone marrow aspiration on three consistently leucopenic workers (the two with WBCs $<4000$ cells $/ \mu 1$ in group $A$, the other in group B) indicated hypoplastic marrow, but no other significant findings. Liver function tests did not differ among the subjects. compared with only one $(8 \%)$ out of 12 workers in group B. Most of the painters with 
Table 5 Results of multiple regression analysis modelling WBC counts

\begin{tabular}{llll}
\hline Variables & $\beta$ coefficients $(95 \%$ CI) & $p$ Value & Mode $R^{2}$ \\
\hline Model 1 (with study groups): & & 0.0062 & 0.142 \\
Study group (group A v control group) & $-1046.6(-1596.0$ to -497.2$)$ & 0.0023 & \\
Study group (group B v control group) & $-890.5(-1470.6$ to -310.6$)$ & 0.0013 & \\
Smoking (pack-years) & $35.4(9.7$ to 61.2$)$ & 0.0259 & \\
Alcohol consumption & $-290.4(-931.8$ to 350.9) & 0.4358 & \\
Model 2 (with log EAA): & $-118.4(-232.5$ to -39.5$)$ & 0.0414 & 0.084 \\
Log EAA & $32.6(5.7$ to 57.6) & 0.0426 & \\
Smoking (pack-years) & $-344.5(-959.1$ to 355.2) & 0.3927 & \\
Alcohol consumption & & & \\
\hline
\end{tabular}

Discussion

The glycol ethers (EGEE, EGME) and their acetates (EGEEA, EGMEA) are widely used as industrial solvents because of their chemical and physical properties. ${ }^{9}$ Animal experiments and human case studies have shown that glycol ethers have the potential for a considerable impact on the haematopoietic and reproductive systems. ${ }^{12} 1011$ Although some data on airborne exposure for EGEE or EGME have been reported, the data on EGEEA are severely limited. ${ }^{4}$ Reported exposure concentrations vary depending on the work process. The exposure concentrations in the present study were lower than those reported in a situation of acute poisoning, ${ }^{12}$ or when used as a cleaning solvent, ${ }^{6}{ }^{13}$ but was close to the concentrations reported when EGEE was used in painting. ${ }^{314}$

Firstly, EGEEA and EGMEA are converted to EGEE and EGME by esterases. Then EGEE and EGME are metabolised to the corresponding alkoxyacetic acids (EAA, MAA; methoxyacetic acids) by oxidation through alcohol dehydrogenase and aldehyde dehydrogenase. ${ }^{15-17}$ The alkoxyacetic acids produced the same degree of testicular toxicity as the parent compounds. Biological monitoring by means of alkoxyacetic acids is very important in occupational exposure, because of their low vapour pressure and high rate of dermal absorption. ${ }^{59}$ The biolological monitoring data are, however, scarce. The concentrations of EAA in group $A$ were significantly higher than those in the control subjects, which indicates that tank crews in group A are widely exposed to EGEEA. The concentration of EAA (mean (SD)) in group A is lower than the $25.0(20.7) \mathrm{mg} / \mathrm{g}$ creatinine in the shipyard painters reported by Lowry. ${ }^{7}$ The correlation coefficient $(0.40)$ of EAA with EGEEA is lower than that (0.85) reported by Groeseneken et al. ${ }^{18}$ These differences might be due to personal respiratory protective equipment and percutaneous absorption.

The possible effects of EGEEA on the haematological system in humans have been reported for the first time in the present study, although the toxic effects of EGEEA on the testes and blood of laboratory animals have been reported. ${ }^{18}$ Whereas normal values for the erythrocyte count and haemoglobin concentration remain quite stable, the normal leucocyte count may show considerable variation within an individual subject. To minimise these problems we examined the workers at the same time, ran the complete blood count within 8 hours of blood sampling, and ruled out such factors as viral infections and medications. Our study showed a significant difference in the mean leucocyte count between the more exposed group A and the control group, although the difference was not clinically significant. Multiple linear regression showed that subjects in groups A and B had lower WBCs than the control group after controlling for smoking and alcohol consumption; EAA concentrations also decreased WBCs. Smoking was, however, shown to increase WBCs. The present study also showed a higher proportion of leucopenia in the shipyard painters. Bone marrow aspiration was done on the three leucopenic workers, and they were shown to have bone marrow hypoplasia. Hence the haematological effects in the painters could be due to bone marrow depression. Our study also showed that granulocytopenia may affect peripheral leucopenia, findings also reported by Larese et al. ${ }^{19}$ Increases in MCV (macrocytosis) without anaemia have also been described recently in workers exposed to organic solvents. ${ }^{19}$ The importance of this finding remains obscure, but may provide a clue to the mechanism for solvent induced haematopoietic hazards. The reason leucocytes but not RBCs, are affected by EGEEA in the present study might be explained by the report of Nagano et $a l,{ }^{1}$ in which leucocytes were affected by a lower dose, and RBCs only by a higher dose of EGEEA.

It was found that EGEEA had been used for several years and other myelotoxic factors such as benzene, ionising radiation, and lead were ruled out by detailed hygiene evaluations including analyses of blood lead concentrations, and evaluation of exposure in the environment and during leisure time. Chronic liver disease was also ruled out.

The high rate of possible haematological effects among shipyard painters and a hygienic evaluation of the working environment suggests that EGEEA might be toxic to bone marrow. The present study is important as it is the first report suggesting a possible haematological effect despite the fact that the work has such limitations as lack of haematological data before the start of employment and is a cross sectional study.

Further study to confirm the haematological effects in workers exposed to these compounds must be carried out, in view of their implications for future haematological health, and the widespread use of these solvents in industrial processes.

The shipyard painters were exposed to mixtures of EGEEA, toluene, xylene, and methyl isobutyl ketone, etc, and the possible combined effects on human health also remain to be studied.

\footnotetext{
1 Nagano K, Nakayama E, Koyano M, et al. Mouse testicular atrophy induced by ethylene glycol monoalkyl ethers. $\mathcal{F} a p \mathcal{F}$ Ind Health 1979;21:29-35.

2 Parsons CE, Parsons ME. Toxic encephalopathy and "granulopenic anemia" due to volatile solvents in industry: report of two cases. F Ind Hyg Toxicol 1938;20:124-33.

3 Sparer J, Welch LS, McManus K, et al. Effect of exposure to ethylene glycol ethers on shipyard painters: I. Evaluation of exposure. Am f Ind Med 1988;14:497-507.

4 Sakai T, Araki T, Masuyama Y. Determination of urinary alkoxyacetic acids by a rapid and simple method for alkoxyacetic acids by a rapid and simple method for
biological monitoring of workers exposed to glycol ethers and their acetates. Int Arch Occup Environ Health 1993;64: and their
} 
5 Guest D, Hamilton ML, Deisinger PJ, et al. Pulmonary and percutaneous absorption of 2-propoxyethyl acetate and 2 -ethoxyethyl acetate in beagle dogs. Environ Health Perspect 1984;57:177-84.

6 Zavon MR. Methyl cellosolve intoxication. Am Ind Hyg Assoc f 1963;24:36-41.

7 Lowry LK. The biological exposure index: its use in assessing chemical exposures in the workplace. Toxicology 1987;47:55-69.

8 Trihaut R, Dutertre-Catella H, Phu-Lich N, et al. Comparative toxicological study of ethylglycol acetate and butylglycol acetate. Toxicol Appl Pharmacol 1979;51:117-27.

9 World Health Organization Environmental health criteria 115 : 2-methoxyethanol, 2-ethoxyethanol, and their acetates. Geneva: WHO, 1990.

10 Welch LS, Cullen MR. Effect of exposure to ethylene glycol ethers on shipyard painters: III. Hematological effects. $A m$ fInd Med 1988;14:509-26.

11 Welch LS, Schrader SM, Turner TW, et al. Effect of exposure to ethylene glycol ethers on shipyard painters: II. exposure to ethylene glycol ethers on shipyard painters

12 Greenburg L, Mayers MR, Goldwater LJ, et al. Health hazards in the manufacture of "fused collars." I. Exposure to ethylene glycol monmethyl ether. Fournal of Industrial Hygiene and Toxicology 1938;20:134-47.

13 Ohi G, Wegman DH. Transcutaneous ethylene glycol monomethyl ether poisoning in the work setting. $f$ Occup Med 1978;20:675-6.

14 Clapp DE, Smallwood AW, Moseley C, et al. Workplace assessment of exposure to 2-ethoxyethanol. Appl Ind Hyg 1987;2:183-7.

15 Foster PMD, Lloyd SC, Blackburn DM. Comparison of the in vivo and in vitro testicular effects produced by methoxy, ethoxy and n-butoxy acetic acids in the rat. Toxicology 1987;43:17-30.

16 Johanson G. Aspects of biological monitoring of exposure to glycol ethers. Toxicol Lett 1988;43:5-21.

17 Miller RR, Hermann EA, Langvardt PW, et al. Comparative metabolism and disposition of ethylene glycol monomethyl ther and propylene glycol monomethyl ether in male rats. Toxicol Appl Pharmacol 1983;67:229-37.

18 Groeseneken D, Veuleman H, Masschelein R. Urinary excretion of ethoxyacetic acid after experimental human excretion of ethoxyacetic acid after expe

19 Larese F, Fiorito A, Zotti RD. The possible haematological effects of glycol monomethyl ether in a frame factory. $\mathrm{Br} \mathcal{F}$ Ind Med 1992;49:131-3.

\section{Occupational and Environmental Medicine - http://www.occenvmed.com}

Visitors to the world wide web can now access Occupational and Environmental Medicine either through the BMJ Publishing Group's home page (http://www.bmjpg.com) or directly by using its individual URL (http://www.occenvmed.com). There they will find the following:

- Current contents list for the journal

- Contents lists of previous issues

- Members of the editorial board

- Subscribers' information

- Instructions for authors

- Details of reprint services.

A hotlink gives access to:

- BMJ Publishing Group home page

- British Medical Association website

- Online books catalogue

- BMJ Publishing Group books.

The web site is at a preliminary stage and there are plans to develop it into a more sophisticated site. Suggestions from visitors about features they would like to see are welcomed. They can be left via the opening page of the BMJ Publishing Group site or, alternatively, via the journal page, through "about this site". 